\title{
The October 2000 flood at the Po river and Sesia river junction
}

\author{
M. Fugazza ${ }^{1}$, P. Magri ${ }^{1}$, L. Natale ${ }^{1}$ \& F. Savi ${ }^{2}$ \\ ${ }^{1}$ University of Pavia, Italy \\ ${ }^{2}$ University of Rome "La Sapienza", Italy
}

\begin{abstract}
During the October 2000 flood more than $80 \mathrm{~km}^{2}$ of rural and settled areas located in the floodplain close to the junction of the Sesia and Po rivers were inundated. The flooding was studied combining three different mathematical models: a 1D model, a 2D model and a lumped, conceptual model.

The propagation of the flood wave along a reach of $76 \mathrm{~km}$ of the Po river was carried out by applying the 1D model and considering the outflow through the breaches in the overtopped levees. The outflow inundated the Casale Monferrato floodplain and exited into the Po river where it joins with Sesia river. The inundation of the floodplain was simulated by means of both the 2D mathematical model and the conceptual model.

The 2D computational grid was deduced from the LiDAR digital elevation model of the river junction integrated by bathymetric surveys. The $2 \mathrm{D}$ model proved to be more accurate in simulating the dynamics of the flooding when compared to the 1D model. This more traditional approach does not seem acceptable since discrepancies in the water surface elevations computed by means of 2D and 1D models are as large as the levees freeboard usually adopted in real world design of the Po river levees.
\end{abstract}

Keywords: flood propagation, shallow water equations, river junctions.

\section{Introduction}

Historical flood studies are important tools for floodplain management since they provide valuable information that can be used to predict extreme hydrologic events (Chery and Filali [6]), to develop flood forecasting systems (Bates et al. [3]) and to engineer the risk analysis of flood protection systems (Ganoulis [8]). 
Barriendos and Rodrigo [2] analyzed the severity and frequency of historical flood events in different Spanish rivers.

Stanescu et al. [13] considered more than 750 historical, outstanding floods that occurred across Europe and comparisons between the floods were carried out.

In recent years the frequency and magnitude of floods in this area has been relatively large. In particular, in the last two decades, a lot of severe floods were registered in the north of Italy. A disastrous flood occurred in the southern area of Piedmont Region at the beginning of November 1994 (Cassardo et al. [5]). More recently, in October 2000 the whole Po river basin was concerned by a huge flood. Heavy rainfalls interested the north-western Italian Alps from the upstream reach of the Po river to the Ticino river, causing huge flooding and landslides with significant damages to houses and infrastructures and several life losses. The event effects and the subsequent land planning measures adopted for the risk mitigation were studied by Ratto et al. [11] and Wheatcroft et al. [14].

The October 2000 flood characteristics and features at the Po river and Sesia river junction are considered in the present paper. In that area, the Po river and his tributaries were interested by an exceptional flood as for peak discharge and peak duration. In particular, after 12:00 pm of October $15^{\text {th }}$, the left levees of Po river close to Trino and Palazzolo were overtopped and more than $80 \mathrm{~km}^{2}$ of the protected flood plain were inundated (Fig. 1). Moreover a portion of the flood plain was inundated by the irrigation network due to water coming back from Po river. Afterwards, in the night between 15 and 16 of October the main levees immediately downstream Morano collapsed forming a 70-80 m wide breach.

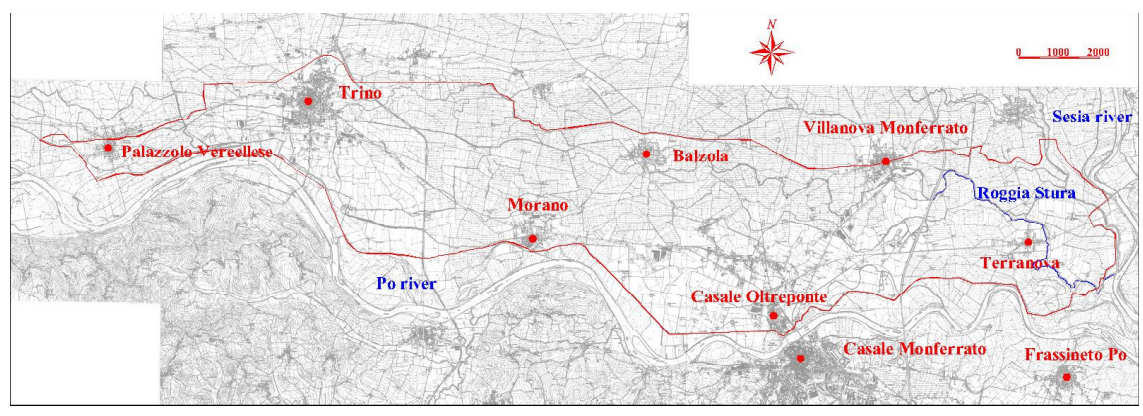

Figure 1: $\quad$ Flooded area in Casale plain.

The flooded area reached its maximum expansion close to Casale Monferrato; the district of Casale Oltreponte was seriously affected, thousands of inhabitants were concerned and infrastructures were damaged; water stage reached $1.50 \mathrm{~m}$ in Terranova village. The water returned from the flood plain to Po river through the outlet of the Roggia Stura irrigation canal (Fig. 1).

Just downstream of the A26 motorway bridge (Fig. 2) water overtopped the right secondary levee and spread in the floodplain; the main body of the flood wave moved towards Frassineto Po, which was not inundated since the $100 \mathrm{~m}$ long insecure main levees were promptly reinforced. Some water took its way upstream, towards the motorway bridge. 


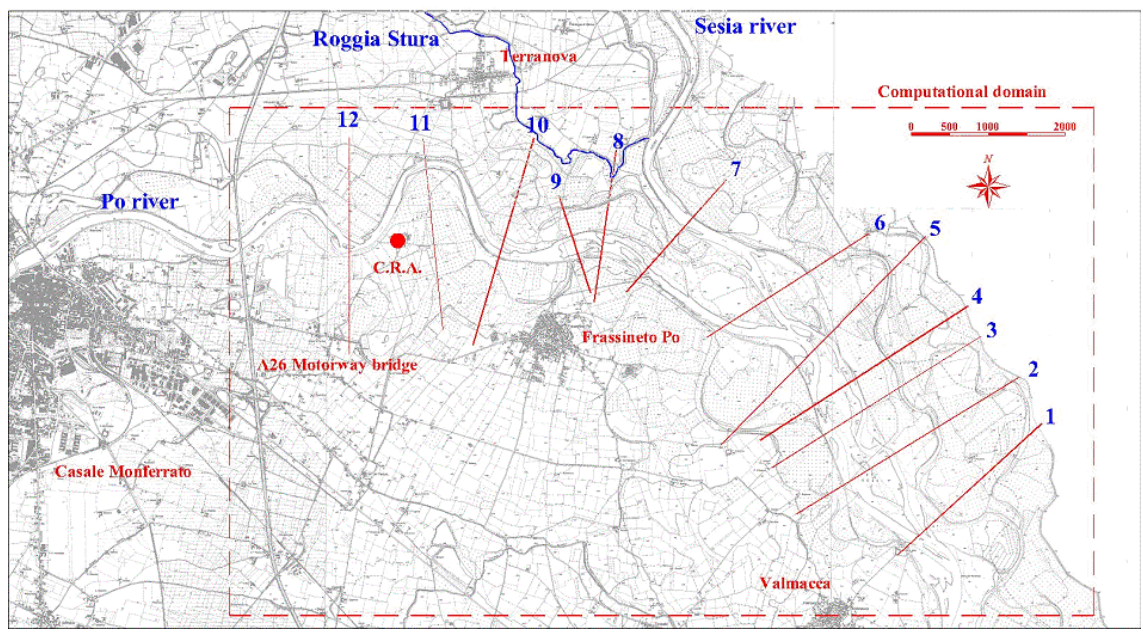

Figure 2: $\quad$ Po and Sesia river junction and computational domain.

\section{Mathematical models}

Channel confluences form an important component of the river systems as they influence the morphology and hydrology of the reaches upstream and downstream of the confluence. River confluences have been studied with mathematical models, field and laboratory investigations because and understanding of the flow structures in these sites is important for prediction of scour and fill. For instance, the influence of differences in beds between the main and tributary channel was studied by Bradbrook et al. [4].

The work presented in the present paper analyzes the flood characteristics at the junction between Po and Sesia, in order to make a comparison between the results obtained with a $1 \mathrm{D}$ and a $2 \mathrm{D}$ model.

The flood event was simulated using three different but interconnected models. The De Saint Venant model reproduced the overall hydraulic aspects of the flood propagation to define the boundary conditions of the $2 \mathrm{D}$ model simulating the flood propagation at the river junction (Fig. 2). The inundation of the Casale Monferrato plain (Fig. 1) was computed by another 2D model. Any of the models considered fixed river bed.

In particular, the 1D model was applied to simulate the flood propagation along a $76 \mathrm{~km}$ long reach of Po river, between two river gauging stations where water stage records are available: discharge hydrograph at the upstream section, Crescentino bridge; water stage hydrograph at the downstream section, Isola S. Antonio bridge.

Other water stage hydrographs were recorded at Casale Monferrato and Valenza bridge. Tanaro river (not included in Fig. 2) and Sesia river are the two main gauged tributaries flowing in, between Crescentino and Isola S. Antonio bridges. 
De Saint Venant equations were integrated using the Preissman implicit scheme (Cunge et al. [7]): the resulting algebraic system of equations was solved using the Thomas algorithm. The river bathymetry was described by 76 cross sections, including 6 bridges and one dam.

The $2 \mathrm{D}$ model was used to simulate the flood propagation at the Po and Sesia river junction, between A26 motorway bridge and Valmacca village as indicated in Fig. 2.

The shallow water equations were integrated by using an explicit finite difference scheme on a staggered, rectangular grid, that constitutes a new version of the solver proposed by Natale and Savi [10], that represents the development of the original idea of Sielecky [12] to include the convective inertia terms.

The computational grid of 121828 elements $(25 \times 25 \mathrm{~m})$ was obtained from the $2 \times 2 \mathrm{~m}$ digital elevation model produced by IRPI Research Unit of Turin, by integrating a river bathymetric survey in the extensive LiDAR survey. The digital elevation model was somewhere corrected to reproduce the bank shape as it was in year 2000, before the recent levee reinforcement works.

The 2D simulation of the inundation of Casale Monferrato plain used a computation grid of 17708 elements of $100 \times 100 \mathrm{~m}$ (Fig. 1). The digital elevation model of the $170 \mathrm{~km}^{2}$ wide area was deduced from 1:10000 official maps (Fig. 2).

\section{Flood propagation from Crescentino to Isola S. Antonio}

The computation of the flood propagation between Crescentino and Isola $\mathrm{S}$. Antonio cross sections considered Manning roughness coefficients $n=0.035 \mathrm{~m}^{-}$ ${ }^{1 / 3} \mathrm{~s}$ for the river and $\mathrm{n}=0.050 \mathrm{~m}^{-1 / 3} \mathrm{~s}$ for the floodplain. The inflows from Tanaro and Sesia rivers were considered.

The results of the 1D model agree with the observed water stages at Casale Monferrato and Valenza bridges and with the time of overtopping of the levees. The outflow from the levee breaches in Palazzolo and Trino and in Morano, afterwards, reduced the Po river discharge of about $1400 \mathrm{~m}^{3} / \mathrm{s}$, as shown in Fig. 3. The peak discharge of Po river at Crescentino, Casale and Isola S. Antonio was about $8400 \mathrm{~m}^{3} / \mathrm{s}, 7200 \mathrm{~m}^{3} / \mathrm{s}$ and $10100 \mathrm{~m}^{3} / \mathrm{s}$, respectively.

\section{Inundation of Casale floodplain}

The 1D model provided the flow rate hydrograph at the A26 motorway bridge, as upstream boundary condition, and the water stage hydrograph at the Valmacca cross section, as downstream boundary condition, for the 2D models.

Since (a) the propagation of the flood wave at the river junction is influenced by the outflow from the Casale Monferrato plain and (b) the models of the river junction and the Casale floodplain are uncoupled, the two models had to be applied in cascade, recursively. First of all, the 1D model was applied by ignoring the contribution of the wave inundating the Casale floodplain in order to estimate the overflow discharge hydrographs at Palazzolo Vercellese, Trino 


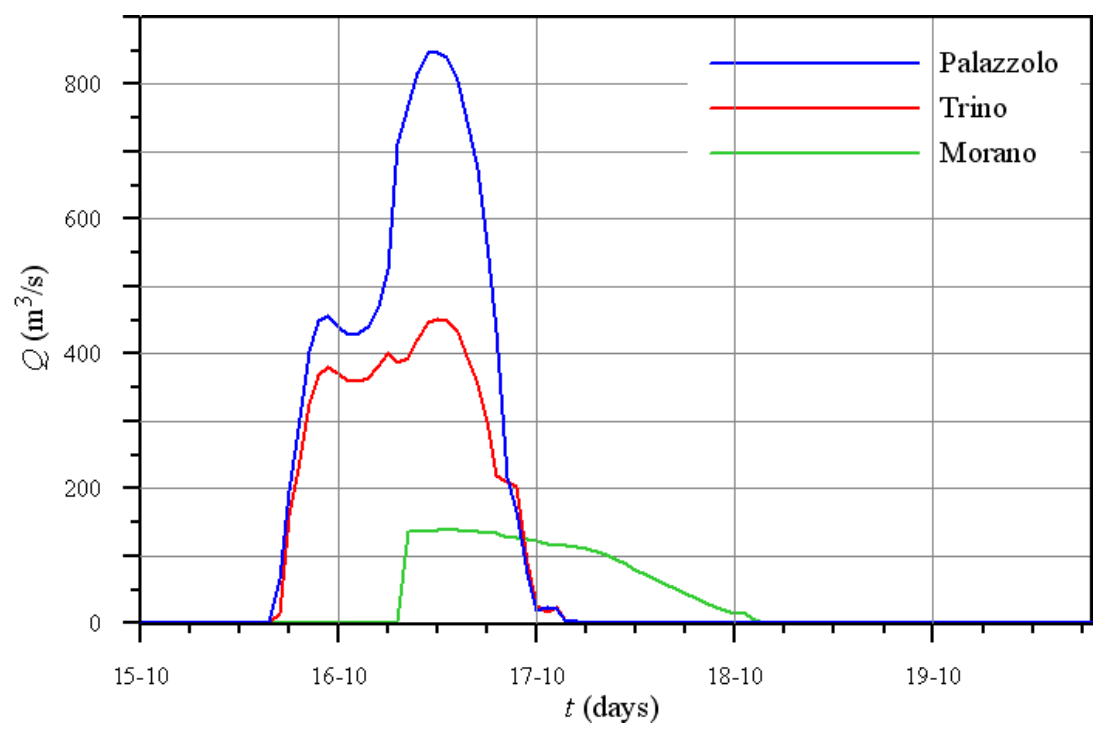

Figure 3: Outflow hydrographs from the Po river.

and Morano and the flow returning to the Po river through the Roggia Stura outlet. Afterwards, the two 2D models were applied by using the boundary conditions previously computed. Computations were repeated until convergence.

Contours of the inundation propagating in the Casale floodplain are shown in Fig. 4: the eastside zone was initially flooded by the Sesia river through the Roggia Stura outlet and it was inundated from upstream only 19 hours later. Fig. 5 shows the computed hydrograph flowing in the Casale plain: the downstream inflow, whose volume is $1 \mathrm{hm}^{3}$, is conventionally represented as negative.

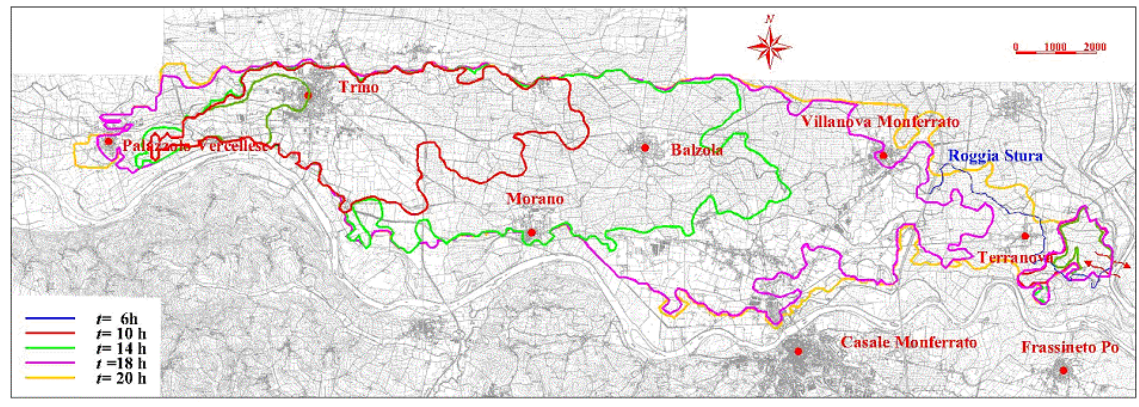

Figure 4: Computed inundation contours at different times.

The inundation of Casale floodplain was also simulated by a lumped hydrological model, which separated the two aspects of the hydraulic phenomenon: translation of the flood wave and storage routing in the plain. 
According to Abbott [1] and Montuori [9], it was assumed that the wave front moves at uniform - flow velocity, $\mathrm{U}_{0}=0.4 \mathrm{~m} / \mathrm{s}$, so that $\mathrm{t}_{\mathrm{F}}=17.4 \mathrm{~h}$ was the travel time from Morano to Roggia Stura outlet. Instead, the celerity of the wave bulk was computed according to the kinematic wave approach, $\mathrm{c}=3 / 2 \mathrm{U}_{0}$, which gives a travel time $t_{w}=11.6 \mathrm{~h}$. The outflow discharge through Roggia Stura outlet was computed by integrating the storage equation.

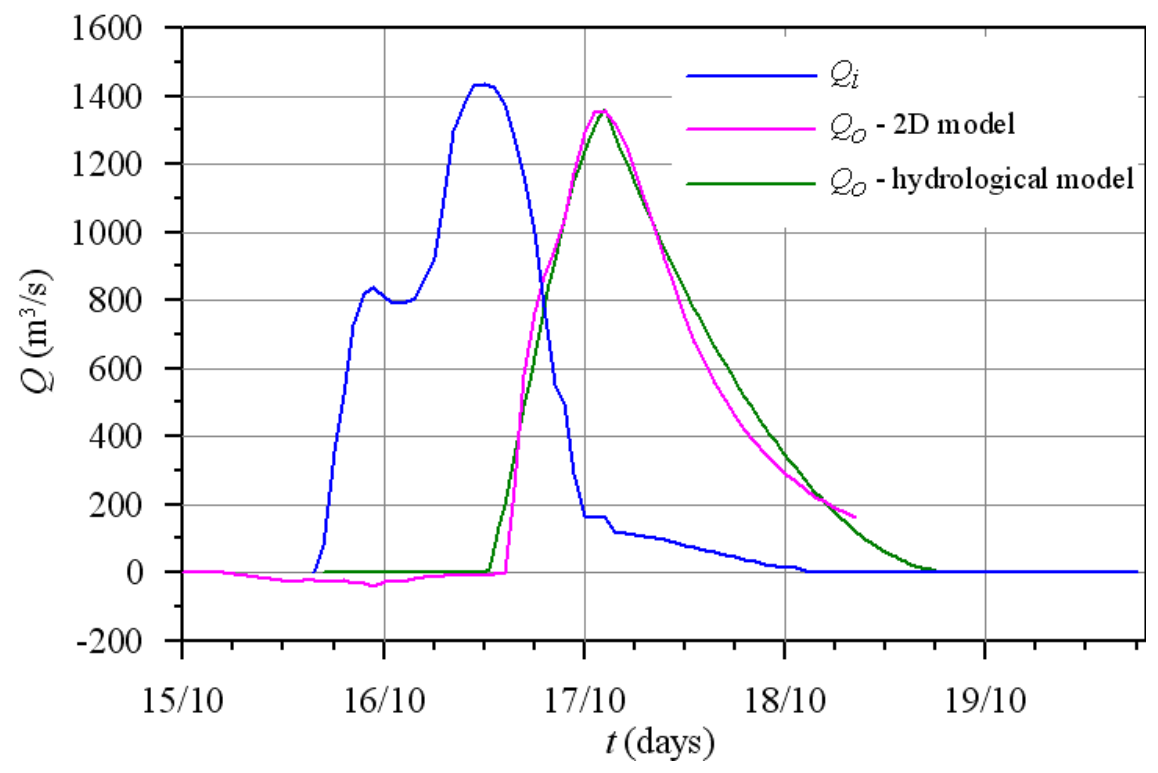

Figure 5: Computed flow-rate hydrographs in and out of the Casale plain.

In applying the storage equation we considered that: (a) no water flowed out from the plain before the wave front reached the downstream section, $t_{F}$ hours after the beginning of the inundation; (b) the water depth at the outlet section increases gradually until the arrival of the wave body, $t_{F}-t_{w}$ hours after the beginning of the outflow. The computed hydrograph is shown in Fig. 5.

\section{Inundation of river junction and conclusions}

Fig. 6 shows the maximum extension of the flooded area: the flow is mainly concentrated in the active river channel, abandoned branches are reactivated, the stable confluence bar is completely submerged. The flow is mainly $2 \mathrm{D}$ so that the water surface profile significantly differs from the average one computed by the gradually - varied flow model, as clearly shown in Fig. 7. This figure compares 1D and 2D transverse water profiles in one cross section. The maximum and the average differences between the water elevations at the two sides of the cross sections were $1.2 \mathrm{~m}$ and $0.7 \mathrm{~m}$, respectively, that resulted comparable with the usual $1.0 \mathrm{~m}$ freeboard adopted in designing Po river levees. 
The maximum water levels computed along a longitudinal profile are compared in Fig. 8: the traditional 1D model underestimates water surface elevations, especially near the riverbanks.

Therefore, the use of simplified methods, such as 1D models, can bring the practitioner to unsafe design of river training works, despite the adoption of ample freeboards; in these cases it is clearly recommended the use of most accurate mathematical models.

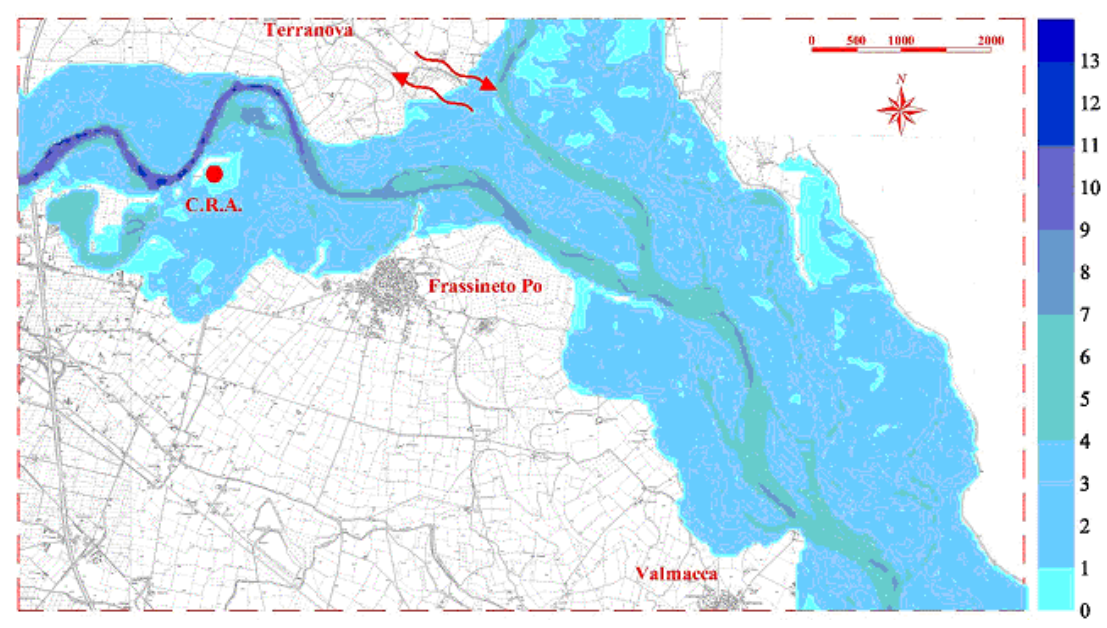

Figure 6: Inundated area at the Po and Sesia junction calculated with the 2D model.

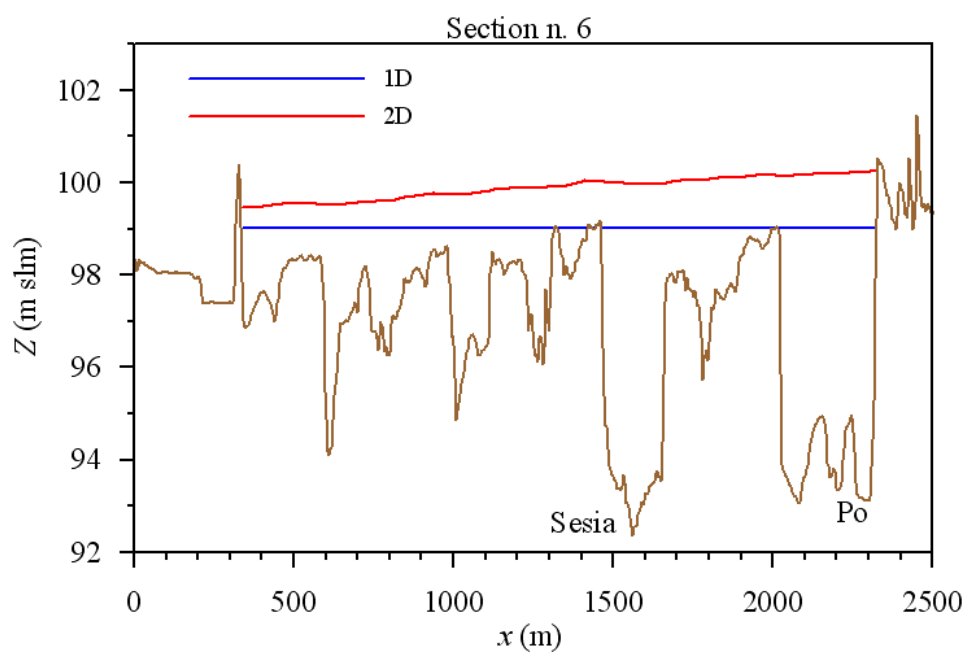

Figure 7: Water profiles along a cross section calculated with $1 \mathrm{D}$ and $2 \mathrm{D}$ models. 


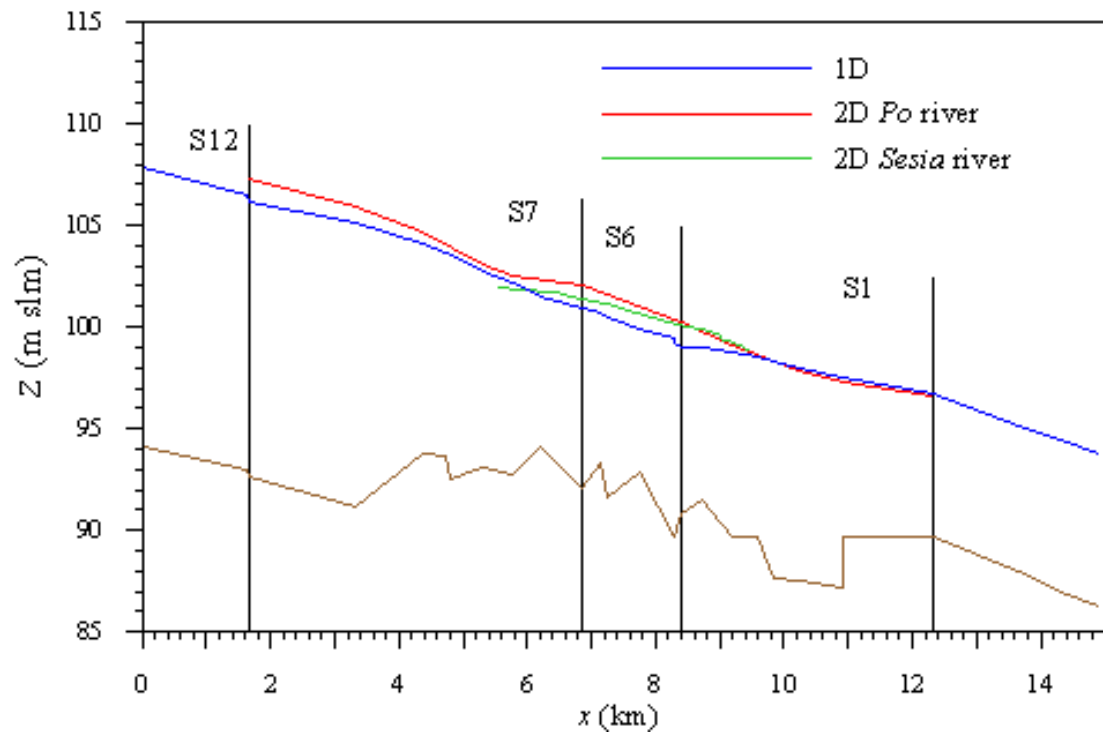

Figure 8: Longitudinal water profiles in the junction area calculated with 1D and 2D models.

\section{References}

[1] Abbott M. B., Computational Hydraulics, Pitman Publishing Ltd, London, 1979.

[2] Barriendos M., Rodrigo F., Study of historical flood events on Spanish rivers using documentary data, Hydrological Sciences Journal, Vol. 51, 2006.

[3] Bates P. D. et al., Development of a European flood forecasting system, Intl. J. River Basin Management Vol. 1, No. 2, 2003.

[4] Bradbrook K. F., Lane S. N., Richards K. S., Biron P. M., Roy A. G., Role of bed discordance at asymmetrical river confluences, Journal of Hydraulic Engineering, 2001.

[5] Cassardo C. et al., The flood of November 1994 in Piedmont, Italy: a quantitative analysis and simulation, Hydrological Processes, 16, 2002.

[6] Chery L., Filali R.., Data bases and their utility to predict extreme hydrologic events, Houille Blanche-Revue Internationale De L'Eau, 2004.

[7] Cunge J., Holly F.M., Verwey A., Practical aspects of computational river hydraulics, Pittman Publ., Boston, 1980.

[8] Ganoulis J., Risk-based floodplain management: A case study from Greece, Intl. J. River Basin Management Vol. 1, No. 2, 2003.

[9] Montuori C., Immissione di una portata costante in un canale vuoto, Atti della Fondazione Politecnica per il Mezzogiorno d'Italia, (VI), Napoli, 1964, (in Italian). 
[10] Natale L., Savi F., Espansione di onde di sommersione su terreno inizialmente asciutto, Idrotecnica, 6, 1991, (in Italian).

[11] Ratto S., Bonetto F., Comoglio C., The October 2000 flooding in Valle d'Aosta (Italy): Event description and land planning measures for the risk mitigation, Intl. J. River Basin Management Vol. 1, No. 2, 2003.

[12] Sielecki A., An energy-conserving difference scheme for the storm surge equations, Monthly Weather Review Vol. 96 (3), 1967.

[13] Stanescu V. A. et al., Floods potential in Europe, regionalization and comparison, Houille Blanche-Revue Internationale De L'Eau, 2004.

[14] Wheatcroft R.A., Hunt L., Lewis R., Stevens A., Formation and evolution of the October 2000 Po river flood deposit: evidence from digital $x$ radiographs, Geophysical Research Abstracts, Vol. 5, 2003. 